Erma Nur Fauziandari" Efektifitas Ekstrak Daun Kelor Terhadap Peningkatan Kadar Hemoglobin Pada Remaja Putri (hal 185-190)

Received

10 Desember 2018
Revisied

20 Februari 2019
Acceptep

16 Juni 2019

\title{
EFEKTIFITAS EKSTRAK DAUN KELOR TERHADAP PENINGKATAN KADAR HEMOGLOBIN PADA REMAJA PUTRI
}

\author{
Erma Nur Fauziandari ${ }^{1}$ \\ Politeknik Kesehatan Karya Husada Yogyakarta \\ Email:erma.nf@gmail.com
}

\begin{abstract}
ABSTRAK
Latar Belakang : Anemia adalah masalah gizi yang sering terjadi di negara berkembang dengan prevalensi terbesar adalah pada anak-anak dan wanita usia subur (15-49 tahun). Kejadian anemia pada wanita usia subur (WUS) adalah 30 persen. Target WHO pada tahun 2025 terjadi penurunan anemia pada WUS yaitu 25 persen. Angka kejadian anemia pada WUS di Indonesia adalah 35,3 persen. Kejadian anemia pada WUS akan berpengaruh terhadap kesehatan reproduksi yaitu melahirkan bayi dengan Berat Badan Lahir Rendah (BBLR) dan komplikasi lain selama kehamilan, persalinan dan nifas. Hasil penelitian Sukidjo (2016) bahwa anemia gizi besi paling banyak di tanggulangi dengan konsumsi zat besi. Menurut beberapa penelitian daun kelor (moringa oliefera) adalah sebagai salah satu sumber zat besi. Daun kelor (moringa oliefera) dikenal mempunyai berbagai macam kandungan gizi. salah satunya adalah zat besi, protein, vitamin A, Vitamin C, kalium dan kalsium. Daun kelor menjadi alternatif untuk mengatasi kondisi anemia karena memiliki kandungan zat besi sebesar 28,2 mg. Daun kelor juga menjadi alternatif untuk pengobatan karena dipercaya mengandung berbagai zat antioksidan.

Tujuan : dari penelitian ini adalah mengetahui efektifitas peningkatan kadar hemoglobin dengan megonsumsi ekstrak daun kelor. Metode : Penelitian ini dilakukan dengan rancangan pre post test design. Dengan observasi yang dilakukan pada sampel sebelum dan sesudah mengkonsumsi ekstrak daun kelor. Sampel pada penelitian ini adalah 15 sampel remaja putri. Hasil : Dengan hasil terdapat perbedaan yang signifikan antara kadar hb sebelum dan sesudah pemberian ekstrak daun kelor. Dengan hasil p value $0,009<0,005$. Berdasarkan $p$ value tersebut maka dapat disimpulkan bahwa ektrak daun kelor efektif untuk meningkatkan kadar hemoglobin pada remaja putri.
\end{abstract}

Kata Kunci :Anemia, ekstrak daun kelor

\section{ABSTRACT}

Background: Anemia is a nutritional problem that often occurs in developing countries with the highest prevalence in children and women of childbearing age (15-49 years). The incidence of anemia in women of childbearing age (WUS) is 30 percent. The WHO target for 2025 has a decrease in anemia at WUS of 25 percent. The incidence of anemia in WUS in Indonesia is 35.3 percent. Anemia in WUS will affect reproductive health, namely giving birth to babies with low birth weight $(L B W)$ and other complications during pregnancy, childbirth and postpartum. The 
results of the study by Sukidjo (2016) that iron nutrition anemia is most often overcome by consuming iron. According to several studies of Moringa leaves (moringa oliefera) is one source of iron.. Moringa leaves (moringa oliefera) are known to have a variety of nutritional content. one of them is iron, protein, vitamin A, Vitamin $C$, potassium and calcium. Moringa leaves become an alternative to overcome the condition of anemia because it has an iron content of 28.2 mg. Moringa leaves are also an alternative to treatment because they are believed to contain various antioxidants. Objective: The purpose of this study was to determine the effectiveness of increasing hemoglobin levels by consuming Moringa leaf extract. This research was conducted with a pre post test design design. With observations made on samples before and after consuming Moringa leaf extract. The sample in this study was 15 samples of young women.

Result : With the results there are significant differences between $H B$ levels before and after administration of Moringa leaf extract. With the results of $p$ value $0.009<0.005$. Based on the $p$ value, it can be concluded that Moringa leaf extract is effective for increasing hemoglobin levels.

Keywords: Anemia, Moringa leaf extrac

\section{PENDAHULUAN}

Tujuan pembangunan kesehatan adalah terwujudnya sumber daya manusia yang sehat, cerdas dan produktif. Untuk mencapai hal tersebut maka pemerintah menitikberatkan pembangunan kesehatan pada peningkatan kualitas sumber daya manusia. Peningkatan kualitas sumber daya manusia salah satunya adalah dengan menurunkan angka kejadian penyakit tidak menular. Penyakit tidak menular di Indonesia yang saat ini masih banyak terjadi adalah Anemia. Anemia adalah masalah gizi yang sering terjadi di negara berkembang dengan prevalensi terbesar adalah pada anakanak dan wanita usia subur (15-49 tahun). Kejadian anemia pada wanita usia subur (WUS) adalah 30 persen. Target WHO pada tahun 2025 terjadi penurunan anemia pada WUS yaitu 25 persen. Angka kejadian anemia pada WUS di Indonesia adalah 35,3 persen. Kejadian anemia pada WUS akan berpengaruh terhadap kesehatan reproduksi yaitu melahirkan bayi dengan Berat Badan Lahir Rendah (BBLR) dan komplikasi lain selama kehamilan, persalinan dan nifas. Hasil penelitian Sukidjo (2016) bahwa anemia gizi besi paling banyak di tanggulangi dengan konsumsi zat besi. Menurut beberapa penelitian daun kelor (moringa oliefera) adalah sebagai salah satu sumber zat besi. Daun kelor (moringa oliefera) dikenal mempunyai berbagai macam kandungan gizi. salah satunya adalah zat besi, protein, vitamin A, Vitamin C, kalium dan kalsium. Daun kelor menjadi alternatif untuk mengatasi kondisi anemia karena memiliki kandungan zat besi sebesar 28,2 mg. Daun kelor juga menjadi alternatif untuk pengobatan karena dipercaya mengandung berbagai zat antioksidan. Rumusan masalah dalam penelitian ini adalah ekstrak daun kelor efektif dalam meningkatkan kadar hemoglobin pada remaja putri

\section{METODE PENELITIAN}

Jenis penelitian ini adalah penelitian kuantitatif dengan menggunakan pendekatan pre eksperimen. Penelitian ini dilakukan dengan rancangan the one group pretest-posttest design dimana observasi dilakukan sebanyak dua kali, yaitu sebelum dan sesudah eksperimen. Teknik pengambilan sampel dalam penelitian ini adalah puposive sampling yaitu pengambilan sampel berdasar kriteria inklusi dan eksklusi. Dengan kriteria inklusi remaja putri usia 17-24 tahun dan kriteria ekslusi adalah remaja putri yang menderita penyakit kronis. Jumlah sampel dalam penelitian ini adalah 15 remaja putri usia 15-24 tahun. Penelitian ini di lakukan di AKES Karya Husada Yogyakarta pada bulan SeptemberNovember 2018. 


\section{HASIL DAN PEMBAHASAN}

Hasil Penelitian

Hasil penelitian ini berupa tabel distribusi frekuensi kenaikan kadar hb sebelum dan setelah pemberian ekstrak daun kelor.

\subsubsection{Tabel distribusi frekuensi rerata} kenaikan kadar Hb pada remaja putri

\begin{tabular}{|c|c|c|c|}
\hline $\begin{array}{l}\mathrm{N} \\
\mathrm{O}\end{array}$ & Sampel & $\begin{array}{c}\text { Mean pre } \\
\text { test }\end{array}$ & $\begin{array}{c}\text { Mean Post } \\
\text { test }\end{array}$ \\
\hline 1 & $\begin{array}{l}\text { Eksrak daun } \\
\text { kelor }\end{array}$ & 10.62 & 11,8133 \\
\hline
\end{tabular}

Berdasarkan tabel diatas dapat disimpulkan bahwa rerata kadar hb setelah mengkonsumsi ekstrak daun kelor lebih tinggi daripada rerata kadar hb sebelum mengkonsumsi ekstrak daun kelor. Analisa data dengan menggunakan Paired $T$ test diperoleh beberapa hasil yang dapat dijadikan kesimpulan. Nilai korelasi antara dua variabel adalah 0,419 yang berarti bahwa hubungan antara dua variabel kuat dan positif. Hasil sig (2-tailed) bahwa nilai $\mathrm{p}$ value adalah 0,009 maka dapat disimpulkan bahwa $\mathrm{p}$ value $<0,05$ maka terdapat peningkatan kadar $\mathrm{Hb}$ sebelum dan setelah pemberian ekstrak daun kelor.

\section{Pembahasan}

Berdasarkan hasil penelitian tersebut maka dapat disimpulkan bahwa ekstrak daun kelor efektif dalam meningkatkan kadar hemoglobin pada remaja putri. Hasil ini sejalan dengan penelitian dari Rahmawati (2017) yang menyatakan bahwa kadar hemoglobin ibu hamil trimester 2 dan trimester 3 mengalami peningkatan setelah diberikan ekstrak daun kelor. Hasil ini juga sejalan dengan penelitian Yulianti (2015) yang menyatakan bahwa konsumsi ekstrak daun kelor berpengaruh terhadap peningkatan kadar hemoglobin pada remaja putri. Odura E. (2008) menyebutkan bahwa dalam 100 gram daun kelor mengandung zat besi sebanyak 28,29 mg. Maka dari hasil penelitian tersebut dapat disimpulkan bahwa daun kelor dapat menjadi alternatif sumber zat besi. Zat besi memiliki fungsi yang penting, yaitu mengangkut oksigen dari paruparu ke jaringan dan mengangkut electron di dalam proses pembentukan energi di dalam sel. Untuk mengangkut oksigen, zat besi harus bergabung dengan protein membentuk hemoglobin didalam sel darah merah dan myoglobin dan myoglobin di dalam serabut otot (Wikipedia, 2017). Apabila kadar zat besi dalam tubuh mengalami penurunan maka akan terjadi penurunan kadar hemoglobin dalam darah sehingga menyebabkan anemia. Anemia defisiensi besi adalah suatu keadaan dimana kadar hemoglobin dalam darah < $12 \mathrm{gr} \%$. Remaja putri lebih beresiko menderita anemia daripada remaja putra. Faktor yang menyebabkan kejadian anemia pada remaja putri adalah: 
1) setiap bulan remaja putri mengalami menstruasi, 2) remaja putri sering kali menjaga penampilan dengan melakukan diet yang salah (Proverawati, 2011). Kejadian anemia pada remaja putri dapat menyebabkan gangguan pertumbuhan dan perkembangan, penurunan produktivitas remaja yaitu menurunnya konsentrasi belajar, kehilangan semangat dan sulit berkonsentrasi. Menurut Adriana (2012) kejadian anemia dapat dicegah dengan mengkonsumsi makanan bergizi seimbang dengan asupan zat besi yang cukup untuk memenuhi kebutuhan tubuh. Berdasarkan penelitian yang telah dilakukan oleh Sudikjo (2016) bahwa pemberian tablet tambah darah masih menjadi prioritas utama dalam menangulangi kejiadian anemia. Selain itu remaja juga dianjurkan untuk memenuhi kebutuhan zat besi dari konsumsi makanan sumber zat besi yaitu dari makanan sumber protein hewani, protein nabati dan sumber vitamin $\mathrm{C}$ yaitu daging merah, ikan, telur, sayuran hijau seperti bayam, kangkung, brokoli, jeruk, pepaya, pisang dan lainnya (Briawan, 2014). Analisa data yang telah dilakukan dalam penelitian ini menunjukkan bahwa terdapat peningkatan kadar hemoglobin pada remaja setelah diberikan ekstrak daun kelor. Sehingga dapat disimpulkan bahwa konsumsi ekstrak daun kelor dapat dijadikan alternatif untuk mengatasi anemia selain tablet tambah darah. Daun kelor (moringa oliefera) merupakan salah satu jenis tanaman obat multiguna. Daun kelor memiliki efek antioksidan, antikanker, antitumor, antibakteri, antiinflamatori dan anti karsinogenik (Kristina, 2014). Penelitian yang dilakukan di balai penelitian tanaman rempah dan obat pada tahun 2014 menunjukkan hasil bahwa $1 \mathrm{~kg}$ daun kelor dapat menghasilkan kandungan fe sebanyak 54,92 mg (Balittro, dalam Rahmawati, 2017). Daun kelor sangat mudah dijumpai di Indonesia. Tanaman ini berkembang biak secara stek dan dapat dengan mudah tumbuh subur pada daerah dengan curah hujan yang cukup. Menurut penelitian Putra (2010) menyatakan bahwa daun kelor mempunyai manfaat sebagai antioksidan, mencegah terjadinya anemia, membantu menjaga kadar glukosa dalam darah, mempercepat proses pertumbuhan sel dan jaringan baru, antikanker dan antitumor, mencegah terjadinya perdarahan, mencegah penyakit jantung koroner dan sebagai sumber serat.

\section{SIMPULAN DAN SARAN}

\section{SIMPULAN}

Berdasarkan hasil analisis dengan Paired $t$ test maka dapat disimpulkan bahwa Page 188| 
Erma Nur Fauziandari" Efektifitas Ekstrak Daun Kelor Terhadap Peningkatan Kadar Hemoglobin Pada Remaja Putri (hal 185-190)

terdapat perbedaan kadar hemoglobin sebelum dan sesudah pemberian ekstrak daun kelor (Molinga Oliefera pada remaja putri. Artinya bahwa konsumsi ekstrak daun kelor dapat meningkatkan kadar hemoglobin pada remaja putri dan dapat dijadikan alternatif untuk mengatasi kejadian anemia pada remaja putri.

sumber hewani maupun nabati. Sumber zat besi dari hewani adalah daging merah, hati dan sumber protein hewani lainnya. Sumber zat besi dari nabati adalah sayursayuran hijau termasuk didalamnya adalah daun kelor, kangkung, bayam, sawi, brokoli dan lainnya.

\section{DAFTAR PUSTAKA}

Andriani, dkk, 2012. Peranan Gizi dalam siklus kehidupan. Kencana Prenada Media Group. Jakarta

Briawan, D, 2016. Determinan Keberhasilan Program Suplementasi zat besi pada siswi sekolah. Publikasi

Departemen Gizi dan kesehatan masyarakat, 2007. Gizi dan Kesehatan Masyarakat. Raja Grafindo Persada. Jakarta

\section{SARAN}

Bagi remaja putri disarankan untuk menjaga pola makan dengan menu seimbang dimana setiap hari harus mengkonsumsi makanan dengan sumber zat besi baik makanan dari Kemenkes RI, 2013. Riset Kesehatan Dasar (http://www.kemenkes.laporan_ri skesdes 2013. Jakarta.

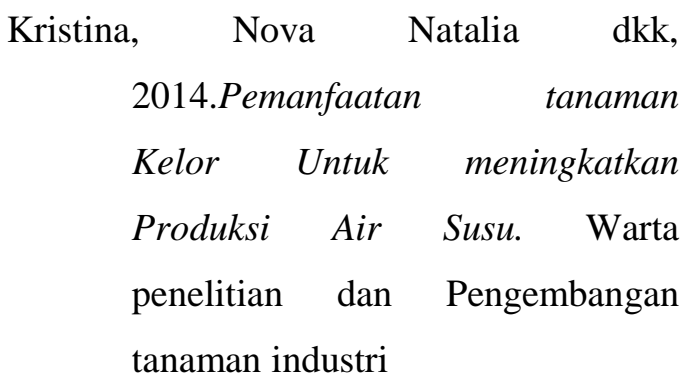

Odura E, Ellis WO, Owusu D. 2008.Nutritional Potential Of Two Leafy Vegetables : Moringa Oliefera and Ipomoea batatos Leaves, Scientific Research and Essay

Proverawati, 2011. Buku Ajar Gizi dan Kebidanan, Nuha Medika, Yogyakarta

Putra, I Wayan Dwika Pratama, dkk, 2016. Identifikasi senyawa Kimia Esktrak Etanol Daun Kelor di Bali. Page 189| 
Jurnal Kesehatan Karya Husada, No 7 Vol 2 Tahun 2019

PISSN 2337649X/EISSN 2655-8874

Erma Nur Fauziandari” Efektifitas Ekstrak Daun Kelor Terhadap Peningkatan Kadar Hemoglobin Pada Remaja Putri (hal 185-190)

Jurnal Indonesia Medicus

Veterinus

Rahmawati, Muti, 2017. Pengaruh ekstrak Daun Kelor Terhadap Peningkatan Kadar hemoglobin Pada Ibu Hamil Trimester 2 dan 3 Di Puskesmas Semanu I. Publikasi Fakultas Ilmu Kesehatan Universitas Aisyah

Wikipedia, 2017, diakses tanggal 2 Desember 2018

Yulianti, Pengaruh Ekstrak Daun Kelor Terhadaap Peningkatan Kadar Hemoglobin Pada Remaja Putri Di SMU Muh. Kupang, Jurnal Unhas 